\title{
The Interconnectedness Between Experience and Intelligence to English Language Teaching
}

\author{
Andrew Philominraj ${ }^{1}$, Maria Bertilla ${ }^{2}$, Bruno Ramírez-Muñoz ${ }^{1} \&$ Andrea Fuentealba $^{1}$ \\ ${ }^{1}$ Universidad Católica del Maule, Talca, Chile \\ 2 Queen Mary's College, India \\ Correspondence: Andrew Philominraj, Departamento de Idiomas, Facultad de Ciencias de la Educación, \\ Universidad Católica del Maule, Región del Maule, Talca, Chile. Tel: 56-71-220-3101. E-mail: andrew@ucm.cl
}

\author{
Received: March 4, 2018 Accepted: April 12, 2018 Online Published: April 14, 2018 \\ doi: $10.5539 /$ elt.v11n5p68 URL: http://doi.org/10.5539/elt.v11n5p68
}

\begin{abstract}
In today's globalized world the importance of English language is beyond discussion. The thrust and focus of all the existing English language teaching theories, approaches and methods is to enable teachers and learners attain optimum success in the teaching and learning of English language. In spite of using all these resources in teaching, English language learning seems a difficult task to be mastered by learners. The contemporary models of communicative competence show that there is much more to the learning of a language and that include the vital component of learners cultural knowledge and awareness. Hence, this article by means of a qualitative descriptive approach aims to explore two concepts: intelligence and experience, and their interconnectedness, which opens new avenues to the teaching of English language.
\end{abstract}

Keywords: English Language teaching, experience, intelligence, learning

\section{Introduction}

The significance of Education in the lives of human beings is an undeniable fact. Education not only forms people, but also helps them to attain dignity in their living. If such is the vitality of Education then all the more importance is to be given to language education. English is a language that is widely used in all spheres of life. English opens doors, provides opportunities and helps human beings to live fully to their dignity gained by education in this modern era. The globalized world has raised English to its highest standards. Therefore, the field of English language teaching, is also expected to keep the momentum to cope with the international demands. Theories, approaches and methods have a huge impact on learning and they also enable the learners to learn a language effectively. Almost all major ELT theories and the various approaches and methods highlight the need for Learner Centeredness in the learning process. It is spelt out by experts that no theory is absolute theory and there are different ways through which an individual learns.

This article is a qualitative descriptive review about the interconnectedness of intelligence and experience, resources that are available to every individual, which constitute as input in English language teaching and learning. The inquiry that is raised in this article is how experience, which is a vital element in every human being, is connected to intelligence, a natural gift that everybody possesses and how these elements together as one resource could contribute substantially towards the successful learning process of the learner.

\section{Reality of English Language Teaching in Multilingual Context}

It is felt that there is a lacuna developed in the multilingual context of English language teaching, a gap between what is taught and the results obtained. Traditional methods used in classrooms, have become an inflexible part of the curriculum; it has much less to contribute to the needs and necessities of the learners of this modern era.

In traditional systems the teachers continue to maintain power in transmitting knowledge, they are a repertoire of knowledge. Referring to Paulo Freire, teachers appear to be "narrating subjects" (Freire, 1972) and the students are passive listeners without having any role to play or any contribution to make. This style of education has less value, for it does not pave way for a meaningful learning amongst learners.

The following quote from Disraeli underlines a great truth, "Traditional learning, with the teacher or trainer spouting facts and figures and with pupils or participants regurgitating the information without deeper 
involvement, is a very ineffective form of learning" (Colin \& Wilson, 2007). This form seems to be administered even today. This is the harsh reality in the field of education. If such is the case, then posing the following question becomes relevant. Is learning always the result of teaching?

There are several studies, which show that most of life learning is not the result of conscious teaching (Illich, 1970; Prabhu, 1987). Of course, we cannot deny the fact that there are certain kinds of learning which take place under certain circumstances and which happen as a result of teaching. In general, the knowledge acquired by a human being during the course of his or her life is acquired outside the classroom (Illich, 1970).

This form of acquiring knowledge by the learners has an in-depth meaning, because his or her learning process produces result in learning the language (Park, 2003). This is precisely because of the interest shown and the responsibility taken up by the learner towards his or her language learning. This creates the basis of what the educational world has announced to be the learner centered model (McCombs \& Whisler, 1997; McCombs, 2013). As a result, there is an increasing awareness of the primacy of the learner's role in the language learning process.

Learner centeredness involves the wholeness of the learners. One aspect of this wholeness is experience, a vital element that constitutes towards any process of learning. The great strength of experiential learning is that it provides an underpinning philosophy that acts as a thread drawing many of the learning theories together to form a unified whole (Moon, 2004; Yardley et al., 2012).

\section{Exploring Experiential Learning}

Experiential learning is the sense-making process of active engagement between the inner world of the person and the outer world of the environment (Colin \& Wilson, 2007). A fundamental and natural way of learning that is available to everyone is through experience. It does not require software or technological tools to support learning and above all, it is not expensive either. All that is required is the opportunity to reflect and think, either alone or in the company of other people. This form of learning is much more effective and long lasting as it involves the learner by creating a meaningful learning experience.

The foremost exponent of experience is John Dewey, who according to Cuffaro used experience as a lens through which he could analyze the interactions of people and their environments (Colin \& Wilson, 2013). Dewey was easily able to connect person and nature, subject and object, knowing and doing, mind and body. In this way, these polarities become connected and the concept of experience creates an organic whole of continuity, process and situation. It is clear that experiencing something is a linking process between action and thought. Dewey (as cited in Swindal, 2014) argued: "Thinking, in other words, is the intentional endeavor to discover specific connections between something which we do and the consequences which result, so that the two become continuous".

Contemplating over the nature of experience is not merely an academic exercise with no real application in the learning environment, but an in-built embedded house of knowledge with real time application. Getting closer to the term experience and by relating our experience is to create a coherent understanding where theory and practice relate to each other. This connection informs and guides us in our practice and enables us to gain insights into the various events in which we are involved. The association between experience and learning is strong and quite inter-related. Wilson (2005) defines learning as a 'relatively permanent change of knowledge, attitude or behaviour occurring as a result of formal education or training, or as a result of informal experiences.' Similarly, Kolb (1984) explained, "Learning is the process whereby knowledge is created through the transformation of experience". Therefore, this cycle of experience constituting knowledge and knowledge in turn contributing to experience leads to the concept of intelligence (Miettinen, 2000).

\section{Exploring Intelligence}

"The idea of intelligence was first proposed in 1885 by Sir Francis Galton who used statistical tools and curves to show that there is a relationship between heredity and genius" (Zahedi \& Ghabanchi, 2014). Later, Howard Gardner, professor of education at Harvard University in 1983 proposed the theory of multiple intelligences (MI) which is based on the cognitive approach (Motah, 2007).

Howard Gardner, the father of multiple intelligence, in his book Frames of Mind, clearly defines intelligence as "the ability to solve problems, or create products, that are valued within one or more cultural settings" (Gardner, 1983). He first identified seven distinct intelligences and added the last two in 1999. Each intelligence type represents a set of capacities that concentrate on two major issues: the solving of problems and the fashioning of significant cultural products (Armstrong, 2003). The ninth intelligence type that has to be taken into account as explained by Richards and Rodgers (2001) is Existential Intelligence. It is the ability to tackle the deep questions 
with respect to the human conditions such as the meaning of life, death and love. This intelligence engages individuals in real world and allows learners to see their place in the big picture and to observe their roles in the classroom, society and the world or the universe. Philosophers, theologians, life coaches and cosmologists are among those who have high level of existential intelligence (Gardner, 1999).

There is a lack of clarity with regard to the source of this ability or the proper means of testing it. Yet, there prevails an unwritten law about the knowledge of intelligence being genetic. A misconception that most of the people in today's society hold on is that, a boy or a girl born of an uneducated parent will never study nor arise to the standards of the society. This to the common understanding is less comprehensible. Therefore, human beings can be trained and pruned through experience; thus, the non-genetic factor can be developed and activated.

There is a considerable agreement that physical traits are most straightforwardly genetic, that aspects of temperament are also largely genetic; but when one comes to the aspects of cognitive style or personality, the case for high heritability is far less convincing. (Gardner, 1983).

Even the process of language learning is quite innate in human beings, which is clearly referred in the innateness hypothesis by Noam Chomsky, who states that "language acquiring process is not grounded exclusively on learning, but is also reliant on an inborn knowledge of the essential grammar common to all languages" (Chomsky, 2004).

According to Gardner, (as stated by Maftoon \& Sarem, 2012), human beings differ in terms of eight different kinds of intelligence, that is, visual, mathematical, verbal, kinesthetic, interpersonal, intrapersonal, rhythmic and naturalistic intelligence. There are various tests and surveys one can take up, to find out, which type of ability one is good at and by doing so, end up learning through those media. For instance, if someone is highly kinesthetic then the learner needs a lot of exposure towards TPR (Total Physical Response) in order to learn and develop his/her learning abilities in a non-coercive manner. Hence, through this system a learner uses his intelligence and experience to learn in an effective way.

Gardner on the other hand claims that the summary of MI theory is to individualize and to pluralize. This aspect of individualizing and pluralizing can lead one to experiential learning. The concept of individualizing and pluralizing paves way to experience. It helps the teacher to know the intelligence profile of their students. After knowing the respective profile of the students, the teacher can frame the lesson accordingly, based on the ability of the students. This can be done and attained only through experience.

By individualizing, I mean that the educator should know as much as possible about the intelligences profile of each student for whom he has the responsibility; and, to the extent possible the educator should teach and assess in ways that bring out the child's capacities. By pluralizing, I mean that the educator should decide on which topics, concepts, or ideas are of greater importance, and should then present them in a variety of ways (Gardner, 1983).

It is essential for any learner to be given an opportunity to produce and a context to use the language; in this case English being the target language. Moreover, motivation towards learning the subject plays a vital role; without any encouragement and stimulation, the learner might feel discouraged and there are possibilities for the student to block his/her mind from further learning.

A person will not become an amazing chess player, or even a "patzer", in the lack of a chess board, but in a given environment wherein chess is played, and some encouragement, persons of assurance have an unusual tendency for the acquisition of the skill quickly and attaining a great level of competence (Gardner, 1983).

Given the opportunity of experiential learning, even students with less academic performance can develop or activate their intelligence. Opportunity and motivation play a vital role in experiential learning. Gardner and some of his colleagues proposed the Socio-Educational Model of Language Learning, which suggests that there are two types of motivation. They are a) Integrative (where there is a wish and a positive attitude on the way to the foreign culture and join in to be a member of it), and b) instrumental (an aim to acquire a foreign language to practice it for a precise purpose, for example, job opportunities and further education) (Eherman et al., 2003).

With regard to opportunities, learners who are in the process of learning a foreign language do not have a wider context for them to produce and practice their target language; hence, peer interaction is a helpful technique to overcome this hassle. Peer interaction (PI) is a setting where learners discuss their identity, role and relationships (Philp et al., 2014). This whole experience of interacting in a context can foster their production and can help them learn more by engaging in meaningful communication. Thereby, it allows the class to be learner centered and not teacher centered. The teacher in this case is only a guide/facilitator and "the learning paradigm is different from the instructional paradigm in that the former is much more interactive and integrative; it focuses 
not only on what is learned but also on how knowledge is acquired" (Philominraj \& Kewlani, 2016).

In the $21^{\text {st }}$ century education, students are exposed to multi technological gadgets, but still they are unable to learn a language. The reason for this present difficulty is that their learning process is not facilitated properly or that there might be a lack of awareness towards technology as a learning tool. Learners' necessity for training has not been completely considered. Therefore, students have to repeatedly depend on their existing awareness and competence in evidence and communications technology (ICT) while working in an online language learning setting (Heiser et al., 2013). Thus, experiential learning should be guided by the teacher even in online learning environments. Gardner (1983) opines that only when one is given an opportunity can he/she be exposed to express his/her intelligence; this aspect can also be considered in terms of technology as a pedagogical tool and considered while teaching students a language. Moreover, the students should be guided and provided more knowledge and an opportunity to train them in using the particular technological tool for effective learning.

The aforementioned factors require the use of classroom based experiential learning, which could make learners aware of the usage of English language in the real world (Schwartz, 2012). Furthermore, it is fundamental for the learner to be aware of the importance of the topic being taught; henceforth, it is the teacher's duty to keep these aspects clear during the class by eliciting the students about the benefits of the structure and language being taught, or the importance of the particular unit in real life situations. Thereby, the learner will become aware and will use his/her previous experience and will also gain intelligence to be more productive in the classroom.

Intelligence is not a machine that could run in isolation. Intelligence is in every human being, in all the living creatures and man needs support for its growth. There is no one-way teaching for human beings to develop into great personalities. Intelligence is a feature, which will not be developed in remoteness. "Intelligence will not grow in isolation, but in someone who is unusual; so it is essential to focus on such situations and roles wherein intelligence dwells in a central place" (Gardner, 1983).

\section{The Interconnectedness of Experiential Learning and Intelligence}

The theoretical aspects above mentioned show that there is much interconnectedness between intelligence and experience. Hence, it is experience what activates intelligence and makes people gain knowledge and understanding of newer real life situations, in different and diverse settings.

Every human being is capable of using all the intelligences that he or she possesses. To trigger intelligence, one must open to a world of opportunities where an individual is capable of experiencing and practicing. Opportunities are not found in vacuum, but they can be sought through experience. Especially, an individual must give way to experience only when he/she is involved and exposed to the reality of the situation. Only through this way, the individual can learn a language and its connections to reality. That is, one must give way to experience; only when one is involved and exposed in the reality of the context, one can learn a language and its usage. "Individuals are different from each other in aspects such as: to understand intricate ideas, to adjust in an appropriate way to the environment, to gain knowledge from experience, to get involved in different ways of reasoning and to succeed by facing those obstacles by thinking effectively" (Maftoon \& Sarem, 2012). However, learning is an integral element in one's life; therefore, it is up to the individual to activate it through experience.

\section{Conclusion}

All approaches and methods aim to enable learners to learn the language effectively. There are methods that are learner centered but majority of them are not so, however, each one of them emphasizes on the learning process of the learner. This learning process is considered a major criterion while constructing a specific teaching method. In the teaching learning process of English language, there are several methods that are implemented and have produced results, and at times, not so favorable results as one could expect. All teaching methods have been enriched the lives of language learners and teachers. It is clear that no method is the final one, and no method has the ultimate word in this process of teaching and learning, which undoubtedly, is a complex phenomenon.

The two concepts, experience and intelligence, taken for study in this article clearly reveals that experience molds an individual to learn many things in life. It creates an impact in the process whereby the lessons taught stay embedded or impregnated in one's mind resulting in a pattern, which is used to understand reality and to use the language. Intelligence may be developed and grown through the exposure to concrete situations inside and outside the classroom. The overall exploration in this study revealed that these two concepts of experience and intelligence not only constitute enriching resources, but their interconnectedness may generate enduring learning in the English language teaching, which though is not a substantial evidence but remains factual. Finally, the teaching practices that sprout from the interconnectedness from experience and intelligence could be considered as a compliment to all those existing teaching methods. 


\section{References}

Armstrong, T. (2003). The Multiple Intelligences of Reading and Writing: making the words come alive. Association for Supervision and Curriculum Development 1703 N. Beauregard St.

Chomsky, N. (2004). Knowledge of Language as a Focus of Inquiry. In B. Lust, \& C. Foley (Eds.), First language acquisition: The essential readings (pp. 15-24). Malden, MA: Blackwell

Colin, B., \& John, P. W. (2007). Experiential learning- A best practice handbook for educators and trainers. London and Philadelphia: Kogan page.

Colin, B., \& John, P. W. (2013). Experiential learning: A handbook for education, training and coaching (3rd Edition). London: Kogan page.

Eherman, M. E., Leaver, B. L., \& Oxford, R. L. (2003). A brief overview of individual differences in Second Language Learning. System, 31(3), 313-330. https://doi.org/10.1016/S 0346-251X(03)00045-9

Freire, P. (1972). Pedagogy of the oppressed. London: Penguin.

Gardner, H. (1983). Frames of mind: The theory of multiple intelligences. New York: Basic Books.

Gardner, H. (1993). Multiple intelligences: The theory in practice. New York: Basic Books.

Gardner, H. (1999). Intelligence reframed: multiple intelligences for the first century. New York: Basic Books.

Heiser, S. L., Stickler, U., \& Furnborough, C. (2013). Ready, Steady, Speak- Online: Student training in the use of an online synchronous conferencing tool. Calico Journal, 30(2), 226. https://doi.org/10.11139/cj.30.2.226-251

Kolb, D. A. (1984). Experiential Learning. NJ: Prentice Hall, Eaglewood Cliffs.

Illich, I. (1970). Deschooling Society. London: Calder and Boyars Ltd.,

Maftoon, P., \& Sarem, S. W. (2012). The Realization of Gardners' Multiple Intelligences (MI) Theory in Second Language Acquisition (SLA). Journal of Language Teaching and Research, 3(6), 1233-1241. http://doi.org/10.4304/j1tr.3.6.1233-1241

McCombs, B. L. (2013). The learner centered model: Implications for research approaches. In J. Cornelius-White, R. Motschnig-Pitrik, \& M. Lux (Eds.), Interdisciplinary handbook of the person-centered approach. Springer, New York, NY. https://doi.org/10.1007/978-1-4614-7141-7_23

McCombs, B. L., \& Whisler, J. S. (1997). The learner centered classroom and school; strategies for increasing student motivation and achievement. San Francisco: Jossey-Bass Publishers.

Miettinen, R. (2000). The concept of experiential learning and John Dewey's theory of reflective thought and action. International Journal of Lifelong Education, 19(2), 54-72. https://doi.org/10-1080/026013700293458

Moon, J. A. (2004). A handbook of reflective and experiential learning: Theory and practice. London and New York: RoutledgeFalmer.

Motah, M. (2007). Proceedings from Informing Science and IT Education Joint Conference 2007: Study of the Influence of Multiple Intelligences and the use of Soft Skills in Project Write-up among IT and Non-IT Students: A research paper. Ljubljana, Slovenia

Park, C. (2003). Engaging students in the learning process: the learning journal. Journal of Geography in Higher Education, 27(2), 183-199. https://doi.org/10.1080/03098260305675

Philp, J., Adams, R. J., \& Iwashhita, N. (2014). Peer Interaction and Second Language Learning. New York: Routledge.

Philominraj, A., \& Mayuri, K. (2016). Learner Centeredness- A Myth or a Reality? International Journal of English: Literature, Language and Skills, 4(4), 92-97.

Prabhu, N. S. (1987). Second language pedagogy. Toronto: Oxford University Press.

Richards, J. C., \& Rodgers, T. S. (2001). Approaches and methods in language teaching. Cambridge: Cambridge University Press. https://doi.org/10.1017/CBO9780511667305

Schwartz, M. (2012). Best practices in experiential learning. Learning and teaching office. Ryerson University. Retrieved from https://www.ryerson.ca/content/dam/lt/resources/handouts/ExperientialLearningReport.pdf

Swindal, J. (2014). Action and existence: A case for agent causation. New York: Palgrave Macmillan. 
Wilson, J. P. (2005). Human Resource Development. Learning and Training for Individuals and Organizations. Kogan Page, London.

Yardely, S., Teunissen, P. W., \& Dornan, T. (2012). Experiential learning: AMEE guide No.63. Medical Teacher, 34(2)-e102-e115. https://doi.org/10.3109/0142159x.2012.650741

Zahedi, Z., \& Zargham, G. (2014). The relationship between logical, naturalist intelligences and learning grammar for EFL learners at elementary level. Theory and Practice in Language Studies, 4(2), 403-410. https://doi.org/10.4304/tpls.4.2.403-410

\section{Copyrights}

Copyright for this article is retained by the author(s), with first publication rights granted to the journal.

This is an open-access article distributed under the terms and conditions of the Creative Commons Attribution license (http://creativecommons.org/licenses/by/4.0/). 